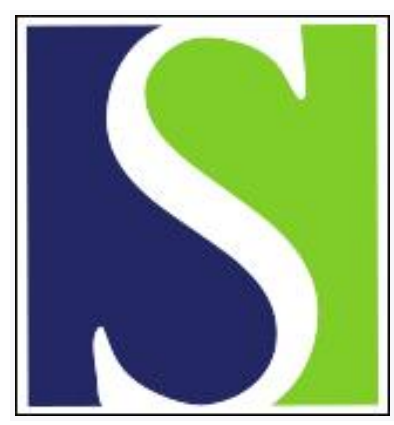

Scand J Work Environ Health 1990;16(5):348-354

https://doi.org/10.5271/sjweh. 1780

Issue date: 00 Oct 1990

Lung cancer and exposure to diesel exhaust among bus garage workers.

by Gustavsson P, Plato N, Lidstrom EB, Hogstedt C

Affiliation: Department of Occupational Medicine, Karolinska Hospital, Stockholm, Sweden.

This article in PubMed: www.ncbi.nlm.nih.gov/pubmed/1701566

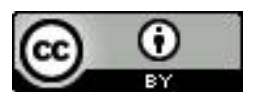




\title{
Lung cancer and exposure to diesel exhaust among bus garage workers
}

\author{
by Per Gustavsson, MD,1, 2 Nils Plato, MSc, ${ }^{1}$ Eva-Britta Lidström, MSc, ${ }^{1}$ \\ Christer Hogstedt, MD ${ }^{1,2}$
}

\begin{abstract}
GUSTAVSSON P, PLATO N, LIDSTRÖM E-B, HOGSTEDT C. Lung cancer and exposure to diesel exhaust among bus garage workers. Scand $J$ Work Environ Health 1990;16:348-54. Mortality and cancer incidence was investigated among the 695 bus garage workers employed as mechanics, servicemen, or hostlers for at least six months in five bus garages in Stockholm between 1945 and 1970. The exposure to diesel exhaust and asbestos was estimated by industrial hygienists. A small excess of lung cancer mortality was found in the cohort when occupationally active men in Stockholm were used as the reference group. A case-referent study was performed within the cohort, six referents being selected for each of the 20 lung cancer cases. The lung cancer risk increased with increasing cumulative exposure to diesel exhaust, but not with cumulative asbestos exposure. The relative risk for lung cancer among the highly exposed men was $2.4(95 \% \mathrm{Cl} 1.3-4.5)$ as compared with those with low exposure. The study indicates that exposure to diesel exhaust increases the risk for lung cancer.
\end{abstract}

Key terms: asbestos, epidemiology, humans, polycyclic aromatic hydrocarbons, PAH.

Exhausts from diesel-fueled vehicles have long been considered a potential cancer hazard due to their chemical composition and mutagenic activity in bacterial test systems (1).

An increased risk for lung cancer was found among railroad workers exposed to diesel exhaust in the United States $(2,3)$ and Canada (4). A small excess of lung cancer was also found among persons with a history of exposure to diesel exhaust in a case-referent study from the United States (5), while another American case-referent study was negative in this respect (6). No increase in the occurrence of lung cancer was found for London transport workers (7) nor for employees at a Swedish bus company (8).

The carcinogenic activity of diesel exhaust has been supported by several recently completed animal inhalation studies (9-13). The mutagenic and carcinogenic properties of diesel exhaust are probably mainly caused by polycyclic aromatic hydrocarbons (PAH), and especially the nitroarenes seem to have a high mutagenic potency (14).

The present study was initiated to investigate the risk of lung cancer in relation to diesel exhaust and asbestos in a cohort of bus garage workers with varying degrees of exhaust exposure.

1 Department of Occupational Medicine, Karolinska Hospital, S-104 01 Stockholm, Sweden.

2 Division of Occupational Medicine, National Institute of Occupational Health, S-171 84 Solna, Sweden.

Reprint requests to: Dr P Gustavsson, Department of Occupational Medicine, Karolinska Hospital, S-104 01 Stockholm, Sweden.

\section{Subjects and methods}

\section{Population}

All the men who had worked as a mechanic, serviceman, or hostler for at least six months in any of five bus garages in Stockholm from 1945 to 1970 were included in the study. Altogether 708 individuals were identified from company records.

Information on name, personal identification number, workplace, job type, and beginning and end of work periods were collected from the records. Life outcome was traced via a computerized register of the living population, via death and burial books of the clerical parishes, and via Stockholm City archives. Underlying causes of death were obtained from Statistics Sweden, and cancer incidence data were obtained from the Swedish Cancer Registry. Mortality was investigated from 1952 to 1986 , and cancer incidence from 1958 to 1984.

Seven cohort members were deceased before 1952 , and six had emigrated. These 13 individuals were excluded from the cohort. Life outcome could be ascertained at the end of follow-up as of 31 December 1986 for all the remaining 695 individuals.

\section{Exposure assessments}

Diesel-powered buses were first introduced in Stockholm in the beginning of the 1930s. During World War II all buses were fueled with generator gas. Since 1945 all buses equipped with combustion engines have been diesel fueled. The intensity of the exposure to diesel exhaust and asbestos, specific for workplace, work task, and calendar-time period, was assessed by incustrial hygienists and structured in a job-exposure matrix. 


\section{Diesel exhaust}

The diesel-exhaust exposure assessments were based on (i) the emission of diesel exhaust, depending on the number of buses, engine sizes, engine running time, and fuel types, (ii) ventilatory equipment and air volume of the garages, and (iii) job types and work practices. Detailed historical data for these parameters were available, but only few exposure measurements had been performed. No single substance is accepted as a marker of diesel-exhaust exposure, although several such substances have been proposed [eg, respirable dust, elemental carbon, nitrous oxides, and PAH (15, 16)]. Thus the available data permitted relative exposures to be estimated, but not absolute exposure levels.

The diesel-exhaust exposure level (exposure intensity) for every work period in the work history was classified on a ratio scale of six degrees. The exposure intensity was set at zero for the unexposed work operations and at 1.0 for the lowest exposures greater than zero. Each successive degree of the scale corresponded to a $50 \%$ increase in intensity: $1.5,2.25,3.38$, and 5.06 .

\section{Asbestos}

Personal sampling of asbestos exposure during brake repair in bus garages in Stockholm was performed in 1987, including reconstruction of earlier exposure conditions (Plato N, unpublished data). These data, and the results of exposure investigations from other bus garages $(17-20)$, were used to estimate the exposure to asbestos for the cohort members, and the timeweighted annual mean exposures were classified on a scale of three degrees: 0,1 and 2 . Level 1 corresponded approximately to a level of 0.08 fibers $\cdot \mathrm{ml}^{-1}$ of air and level 2 to 0.16 fibers $\cdot \mathrm{ml}^{-1}$.

\section{Cumulative exposures}

We calculated indices of cumulative exposures to diesel exhaust and asbestos by multiplying the exposure level by the duration in years for every work period in the work history. The contributions from all work periods were then added for the cumulative exposures to diesel exhaust and asbestos for every individual in the cohort. The diesel-exhaust exposure index ranged from 0 to 112 (median 13), and the asbestos exposure index from 0 to 86 (median 19).

For the case-referent analysis, the diesel-exhaust exposure index was subdivided into four classes $(0-10$, $10-20,20-30$, and $>30$ ) representing each class by a score value ("diesel-exhaust score") of $0,1,2$, or 3 , respectively. The asbestos exposure index was subdivided into the following four classes: $0-20,20-40$, $40-60$, and $>60$.

\section{Analysis}

Cohort and case-referent techniques were used for the analysis. In the cohort analysis the observed mortality was compared with that of a local reference population (the population of greater Stockholm). A second set of local reference rates was also used, with adjustment for occupational activity. This standardization for occupational activity was performed in order to reduce the bias from the "healthy worker effect" (21). Data on occupational activity were recorded in the population and housing census of 1960 , and the mortality from 1961 to 1965 among employed and unemployed persons, specific for age group, sex, and cause of death, has been published by Statistics Sweden (22). From these data, the ratio of the mortality among the employed to that in the general Swedish population was calculated, specific for age group, sex, and cause of death. The ratios were subsequently applied to (multiplied by) the local death rates. The obtained rates reflect the local mortality with adjustment for occupational activity. The adjustment was specific for cause of death and age, but approximate with regard to geographic region and trends in the ratios with calendar time. The procedure for the calculation of the adjusted rates has been described elsewhere (23). The reference rates for cancer incidence were based on national statistics (24).

Expected numbers of deaths and cancers were computed according to the person-year method (25), counting years at risk for each individual, specific for sex, five-year age classes, and five-year calendar-time classes. Both the diesel-exhaust and asbestos exposure indices were time-dependent and were recalculated for every year during the allocation of person-years, and the contributions were referred to the appropriate stratum of the respective exposure index (25).

The "occupational mortality analysis program" (OCMAP-PC) (26) was used for the mortality analyses, and the "epidemiology in Linköping" (EPILIN) program (27) was used for the analysis of cancer incidence.

Dose-response relationships were investigated in a case-referent analysis. A full cohort analysis of internal dose-response relationships using the Cox proportional hazards model (25) was considered. However, the involvement of two time-dependent measures of dose (diesel-exhaust and asbestos exposure indices) led to complicated calculations that were not feasible with the available software. A case-referent analysis, matched with regard to age, permitted calculation and analysis of cumulative exposures without need for dynamic (iterative) recalculation of the exposure indices, as would have been required in a full cohort design. Selection of an appropriate number of controls maintains validity and causes only a small loss of precision (25). This design still permitted the use of both dead and incident lung-cancer cases as end points in the study, which was not the case in the analyses for 
standardized mortality ratio (SMR) using external reference rates.

The cases and referents were selected from the cohort. All individuals with a primary form of lung cancer (eighth revision of the International Classification of Diseases, ICD $8=162.1$, mesotheliomas not included) identified in the register of causes of deaths or in the cancer register were selected as cases. Altogether 20 cases were identified, 12 were registered in both registers, five were registered only in the register of causes of deaths, and three only in the cancer register.

Six referents were selected for every case. The referents were drawn at random and without replacement from those being noncases at the time of diagnosis of the case and born within \pm 2 years of the case, according to the method described by Breslow \& Day (25). The cumulative exposures of the referents were truncated at the time of the diagnosis of the case.

The relative risk for lung cancer was approximated by the odds ratio, calculated by conditional logistic regression (28), with the matched sets kept together. The EGRET (epidemiologic graphics, estimation, and testing) program (29) was used, and the main results were confirmed with the epilog program (30).

\section{Results}

The overall mortality in the cohort equaled the expected when the local rates, adjusted for occupational activity, were used as the reference (table 1). There were 17 lung-cancer deaths, whereas 13.9 would be expected. Altogether, 73 cases of ischemic heart disease were found, whereas 64 were expected. Four cases of esophageal cancer were found, and 2.1 were expected. The observed numbers for other causes of death were close to those anticipated.

Analysis of the lung cancer mortality by increasing cumulative diesel-exhaust exposure indicated no definite evidence for a dose-response relationship, and neither was a dose-response trend found for ischemic heart disease (table 2). The SMR values for both diseases were lowest in the lowest dose category, however. The analysis by cumulative asbestos dose gave no indication of a dose-response for lung cancer (table 3).

The analysis of cancer incidence confirmed the mortality findings, and no additional excesses were found (table 4). Several histological types of lung cancer were represented, and also two mesotheliomas, but the numbers were too few to permit conclusions regarding excesses of individual types.

Table 1. Mortality among bus garage workers, 1952-1986. The reference rates were based on local mortality and on local mortality adjusted for occupational activity. There were 21317.5 person-years of observation. $(\mathrm{O}=$ observed number of deaths, $E=$ expected number of deaths, $S M R=$ standardized mortality ratio, $95 \% \mathrm{Cl}=95 \%$ confidence interval).

\begin{tabular}{|c|c|c|c|c|c|c|c|}
\hline \multirow{2}{*}{ Cause of death ${ }^{a}$} & \multirow{2}{*}{0} & \multicolumn{3}{|c|}{$\begin{array}{c}\text { Stockholm, } \\
\text { occupationally active }\end{array}$} & \multicolumn{3}{|c|}{$\begin{array}{l}\text { Stockholm, } \\
\text { general population }\end{array}$} \\
\hline & & $E$ & SMR & $95 \% \mathrm{Cl}$ & $E$ & SMR & $95 \% \mathrm{Cl}$ \\
\hline All malignant tumors $(140-209)$ & 62 & 56.8 & 109 & $84-140$ & 60.0 & 103 & $79-132$ \\
\hline $\begin{array}{l}\text { Esophageal cancer (150) } \\
\text { Stomach cancer (151) } \\
\text { Bowel cancer (152-153) } \\
\text { Rectal cancer (154) } \\
\text { Liver cancer (155) } \\
\text { Pancreatic cancer (157) } \\
\text { Lung cancer (162) } \\
\text { Prostatic cancer (185) } \\
\text { Bladder cancer (188) } \\
\text { Kidney cancer (189) } \\
\text { Brain tumors (191) } \\
\text { Hematopoietic cancer (200-209) }\end{array}$ & $\begin{array}{r}4 \\
5 \\
1 \\
4 \\
3 \\
2 \\
17 \\
6 \\
1 \\
2 \\
4 \\
6\end{array}$ & $\begin{array}{c}\cdots \\
\cdots \\
\cdots \\
\cdots \\
\cdots \\
13.9 \\
\cdots \\
\cdots \\
\cdots \\
4.9\end{array}$ & $\begin{array}{l}\cdots \\
\cdots \\
\cdots \\
\cdots \\
\cdots \\
\cdots \\
122 \\
\cdots \\
\cdots \\
\cdots \\
\cdots \\
123\end{array}$ & $\begin{array}{c}\cdots \\
\cdots \\
\cdots \\
\cdots \\
\cdots 1-196 \\
\cdots \\
\cdots \\
\cdots \\
45-268\end{array}$ & $\begin{array}{r}2.1 \\
5.1 \\
3.8 \\
2.3 \\
2.0 \\
4.4 \\
14.8 \\
5.0 \\
1.9 \\
2.8 \\
1.8 \\
5.1\end{array}$ & $\begin{array}{r}193 \\
97 \\
26 \\
177 \\
150 \\
46 \\
115 \\
119 \\
52 \\
72 \\
220 \\
117\end{array}$ & $\begin{array}{r}53-494 \\
32-227 \\
7-147 \\
48-453 \\
31-493 \\
5-165 \\
67-184 \\
44-259 \\
1-288 \\
9-259 \\
60-563 \\
43-255\end{array}$ \\
\hline Nervous diseases $(320-389)$ & 5 & $\cdots$ & $\cdots$ & $\cdots$ & 2.6 & 190 & $62-442$ \\
\hline Circulatory diseases $(390-458)$ & 96 & 90.4 & 106 & $86-130$ & 104.7 & 92 & $74-112$ \\
\hline Ischemic heart disease $(410-414)$ & 73 & 64.1 & 114 & $89-143$ & 72.8 & 100 & $78-126$ \\
\hline Cerebrovascular diseases $(430-438)$ & 10 & 11.7 & 85 & $41-157$ & 14.0 & 72 & $34-132$ \\
\hline Respiratory diseases $(460-519)$ & 10 & 7.0 & 143 & $68-262$ & 11.5 & 87 & $42-160$ \\
\hline Asthma, bronchitis, emphysema $(490-493)$ & 4 & $\cdots$ & $\cdots$ & $\cdots$ & 5.3 & 75 & $20-192$ \\
\hline Digestive diseases $(520-577)$ & 8 & 13.2 & 61 & $26-120$ & 15.6 & 51 & $22-101$ \\
\hline Liver cirrhosis (571) & 5 & 8.0 & 63 & $20-146$ & 9.1 & 55 & $18-128$ \\
\hline Genitourinary diseases $(580-629)$ & 2 & 2.6 & 75 & $9-274$ & 3.2 & 63 & $8-230$ \\
\hline Violent death and intoxication (E800-E999) & 21 & 23.4 & 90 & $56-137$ & 25.1 & 84 & $52-128$ \\
\hline Suicide (E950-E959) & 11 & 9.8 & 113 & $56-201$ & 10.5 & 105 & $52-187$ \\
\hline All causes $(0-999)$ & 208 & 204.3 & 102 & $88-117$ & 235.9 & 88 & $76-101$ \\
\hline
\end{tabular}

a Code of the eighth revision of the International Classification of Diseases in parentheses. 
Table 2. Mortality by cumulative exposure to diesel exhaust. The reference rates were based on data from occupationally active men in Stockholm. ( $\mathrm{O}=$ observed number of deaths, $\mathrm{E}=$ expected number of deaths, $\mathrm{SMR}=$ standardized mortality ratio)

\begin{tabular}{|c|c|c|c|c|c|c|c|c|c|}
\hline \multirow{3}{*}{ Cause of death ${ }^{a}$} & \multicolumn{9}{|c|}{ Diesel-exhaust exposure index ${ }^{b}$} \\
\hline & \multicolumn{3}{|c|}{$0-10$} & \multicolumn{3}{|c|}{$10-30$} & \multicolumn{3}{|c|}{$>30$} \\
\hline & 0 & $\mathrm{E}$ & SMR & 0 & $\mathrm{E}$ & SMR & 0 & $E$ & SMR \\
\hline $\begin{array}{l}\text { All causes }(0-999) \\
\text { All malignant tumors }(140-209) \\
\text { Lung cancer }(162) \\
\text { Ischemic heart disease }(410-414)\end{array}$ & $\begin{array}{r}68 \\
19 \\
5 \\
20\end{array}$ & $\begin{array}{l}80.9 \\
21.4 \\
5.15 \\
23.7\end{array}$ & $\begin{array}{l}84 \\
89 \\
97 \\
84\end{array}$ & $\begin{array}{r}61 \\
16 \\
5 \\
21\end{array}$ & $\begin{array}{r}49.4 \\
13.5 \\
3.3 \\
14.8\end{array}$ & $\begin{array}{l}123 \\
119 \\
152 \\
142\end{array}$ & $\begin{array}{r}79 \\
27 \\
7 \\
32\end{array}$ & $\begin{array}{r}74.1 \\
21.9 \\
5.5 \\
25.6\end{array}$ & $\begin{array}{l}107 \\
123 \\
127 \\
125\end{array}$ \\
\hline
\end{tabular}

a Code of the eighth revision of the International Classification of Diseases in parentheses.

$b$ Index of the cumulative exposure to diesel exhaust;see the Subjects and Methods section.

Table 3. Mortality by cumulative exposure to asbestos. The reference rates were based on data from occupationally active men in Stockholm. $(\mathrm{O}=$ observed number of deaths, $\mathrm{E}=$ expected number of deaths, SMR = standardized mortality ratio)

\begin{tabular}{|c|c|c|c|c|c|c|c|c|c|}
\hline \multirow{3}{*}{ Cause of deatha } & \multicolumn{9}{|c|}{ Asbestos exposure index } \\
\hline & \multicolumn{3}{|c|}{$0-20$} & \multicolumn{3}{|c|}{$20-40$} & \multicolumn{3}{|c|}{$>40$} \\
\hline & 0 & $E$ & SMR & 0 & $E$ & SMR & 0 & $E$ & SMR \\
\hline $\begin{array}{l}\text { All causes }(0-999) \\
\text { All malignant tumors }(140-209) \\
\text { Lung cancer }(162) \\
\text { Ischemic heart disease }(410-414)\end{array}$ & $\begin{array}{r}99 \\
25 \\
5 \\
34\end{array}$ & $\begin{array}{r}92.3 \\
24.3 \\
5.8 \\
26.6\end{array}$ & $\begin{array}{r}107 \\
103 \\
86 \\
128\end{array}$ & $\begin{array}{r}41 \\
12 \\
6 \\
15\end{array}$ & $\begin{array}{r}44.9 \\
12.4 \\
3.0 \\
13.9\end{array}$ & $\begin{array}{r}91 \\
97 \\
197 \\
108\end{array}$ & $\begin{array}{r}68 \\
25 \\
6 \\
24\end{array}$ & $\begin{array}{r}67.3 \\
20.1 \\
5.1 \\
23.6\end{array}$ & $\begin{array}{l}101 \\
124 \\
118 \\
102\end{array}$ \\
\hline
\end{tabular}

a Code of the eighth revision of the International Classification of Diseases in parentheses.

$b$ Index of the cumulative exposure to asbestos; see the Subjects and Methods section.

Table 4. Incidence of cancer among the bus garage workers, 1958-1984. The reference rates were based on national statistics. There were 16695 person-years of observation. $(\mathrm{O}=$ observed number of cases, $\mathrm{E}=$ expected number of cases SMR = standardized mortality ratio, $95 \% \mathrm{Cl}=95 \%$ confidence interval)

\begin{tabular}{lrrrr}
\hline Cancer site $^{\mathrm{a}}$ & $\mathrm{O}$ & $\mathrm{E}$ & SMR & $95 \% \mathrm{CI}$ \\
\hline All malignant tumors (140-209) & 91 & 88.6 & 103 & $83-126$ \\
Esophagus (150) & 4 & 1.2 & 327 & $89-837$ \\
Stomach (151) & 6 & 6.7 & 90 & $33-196$ \\
Colon (153) & 4 & 6.3 & 64 & $17-163$ \\
Rectum (154) & 4 & 4.5 & 88 & $24-226$ \\
Liver (155) & 2 & 2.3 & 88 & $10-318$ \\
Pancreas (157) & 2 & 3.5 & 57 & $6-207$ \\
Nose and nasal sinuses (160) & 1 & 0.3 & 376 & $9-2096$ \\
Larynx (161) & 1 & 1.2 & 83 & $2-460$ \\
Lung (162) & 17 & 10.6 & 161 & $94-257$ \\
$\quad$ Squamous-ceil carcinoma & 5 & 4.2 & 118 & $38-275$ \\
Undifferentiated oat-cell carcinoma & 7 & 4.4 & 160 & $64-329$ \\
$\quad$ Adenocarcinoma & 2 & 1.3 & 152 & $17-547$ \\
Prostate (177) & 15 & 15.7 & 96 & $54-158$ \\
Kidney (180) & 3 & 4.3 & 70 & $14-204$ \\
Bladder (181) & 4 & 6.1 & 66 & $18-168$ \\
Malignant melanoma (190) & 5 & 2.1 & 237 & $76-554$ \\
Skin tumors, melanoma excluded (191) & 2 & 2.6 & 78 & $9-282$ \\
Nervous system (193) & 6 & 3.2 & 190 & $70-415$ \\
Hematopoietic organs (200-209) & 6 & 7.5 & 80 & $29-175$ \\
\hline
\end{tabular}

a Code of seventh revision of the International Classification of Diseases in parentheses.

- Including two cases of mesothelioma and one case of alveolar-cell cancer.

The numbers of cases and referents are presented in table 5, and the details of the conditional logistic regression are presented in table 6 . In model 1 the
Table 5. Number of living and deceased persons with lung cancer (cases) and referents from the cohort according to the cumulative diesel-exhaust exposure. (RR = relative risk, $95 \%$ $\mathrm{Cl}=95 \%$ confidence interval)

\begin{tabular}{|c|c|c|c|c|c|}
\hline & \multicolumn{4}{|c|}{ Diesel-exhaust exposure indexa } & \multirow{2}{*}{ Total } \\
\hline & $0-10$ & $10-20$ & $20-30$ & $>30$ & \\
\hline Cases & 5 & 2 & 3 & 10 & 20 \\
\hline Referents & 45 & 15 & 18 & 42 & 120 \\
\hline Total & 50 & 17 & 21 & 52 & 140 \\
\hline Crude RR & $1^{b}$ & 1.20 & 1.50 & 2.14 & . \\
\hline $\begin{array}{l}\text { RR from } \\
\text { logistic } \\
\text { regression }\end{array}$ & $1^{b}$ & 1.27 & 1.56 & 2.63 & . \\
\hline $\begin{array}{l}\text { Fitted } \\
\text { RR from } \\
\text { weighted } \\
\text { regression }\end{array}$ & $1^{b}$ & 1.34 & 1.81 & 2.43 & - \\
\hline $95 \% \mathrm{Cl}$ & - & $1.09-1.64$ & $1.20-2.71$ & $1.32-4.47$ & . \\
\hline
\end{tabular}

a See the Subjects and Methods section for a definition of the index. b Reference category.

diesel-exhaust index score was introduced as factors (indicator variables 0 and 1). The relative risk for lung cancer increased with increasing exposure to diesel exhaust, but the confidence intervals were wide (figure 1).

The diesel score was alternatively introduced as an unfactored variable (regression model 2). The obtained regression coefficient of 0.32 corresponded to a relative risk of 1.37 , interpreted as a $37 \%$ increase in risk for an increase in the dose index score by one unit. The $95 \%$ confidence interval $(95 \% \mathrm{CI})$ for this estimate was narrower than that of model 1 , but included a relative risk of unity. 
The asbestos exposure did not seem to influence the lung cancer risk (models 3 and 4).

There were indications of a dose-response relationship regarding diesel exhaust and lung cancer. (Com-

Table 6. Results of the logistic regression. $(\mathrm{RR}=$ relative risk, $95 \% \mathrm{Cl}=95 \%$ confidence interval)

\begin{tabular}{|c|c|c|c|c|}
\hline Parameter & $\beta$ & $\operatorname{se}(\beta)$ & RR & $95 \% \mathrm{Cl}$ \\
\hline \multicolumn{5}{|l|}{ Model 1} \\
\hline \multicolumn{5}{|l|}{ Diesel-exhaust index ${ }^{a}$} \\
\hline $\begin{array}{l}0-10 \\
10-20 \\
20-30 \\
>30\end{array}$ & $\begin{array}{l}0^{\mathrm{b}} \\
0.236 \\
0.447 \\
0.969\end{array}$ & $\begin{array}{l}\overline{0} \overline{22} \\
0.776 \\
0.649\end{array}$ & $\begin{array}{l}1.0^{\mathrm{b}} \\
1.27 \\
1.56 \\
2.63\end{array}$ & $\begin{array}{c}- \\
0.21-7.72 \\
0.34-7.16 \\
0.74-9.42\end{array}$ \\
\hline \multicolumn{5}{|l|}{ Model 2} \\
\hline Diesel-exhaust score ${ }^{a}$ & 0.318 & 0.211 & 1.37 & $0.91-2.07$ \\
\hline \multicolumn{5}{|l|}{ Model 3} \\
\hline \multicolumn{5}{|l|}{ Asbestos index ${ }^{a}$} \\
\hline $\begin{array}{r}0-20 \\
20-40 \\
40-60 \\
>60\end{array}$ & $\begin{array}{l}0^{\mathrm{b}} \\
0.511 \\
0.230 \\
0.184\end{array}$ & $\begin{array}{l}0.6 \overline{18} \\
0.699 \\
0.789\end{array}$ & $\begin{array}{l}1.0^{\mathrm{b}} \\
1.67 \\
1.26 \\
1.20\end{array}$ & $\begin{array}{c}- \\
0.50-5.60 \\
0.32-5.00 \\
0.26-5.64\end{array}$ \\
\hline \multicolumn{5}{|l|}{ Model 4} \\
\hline Asbestos score ${ }^{a}$ & 0.054 & 0.232 & 1.06 & $0.67-1.66$ \\
\hline
\end{tabular}

Explanation of models:

Model 1:

Logit $P(x)=\alpha+\beta_{1} x_{1}+\beta_{2} x_{2}+\beta_{3} x_{3}$, where

$x_{1}=1$ when diesel exposure $=10-20$, else $x_{1}=0$

$x_{2}=1$ when diesel exposure $=20-30$, else $x_{2}=0$

$x_{3}=1$ when diesel exposure $>30$, else $x_{3}=0$

Model 2:

Logit $P(x)=\alpha+\beta_{1} x_{1}$, where

$x_{1}$ takes the value of the diesel score: $0,1,2$ or 3 .

Models 3 and 4 are analogous, replacing the diesel-exhaust index with the asbestos index.

a See the Subjects and Methods section for a definition of the index or score.

b Reference category.

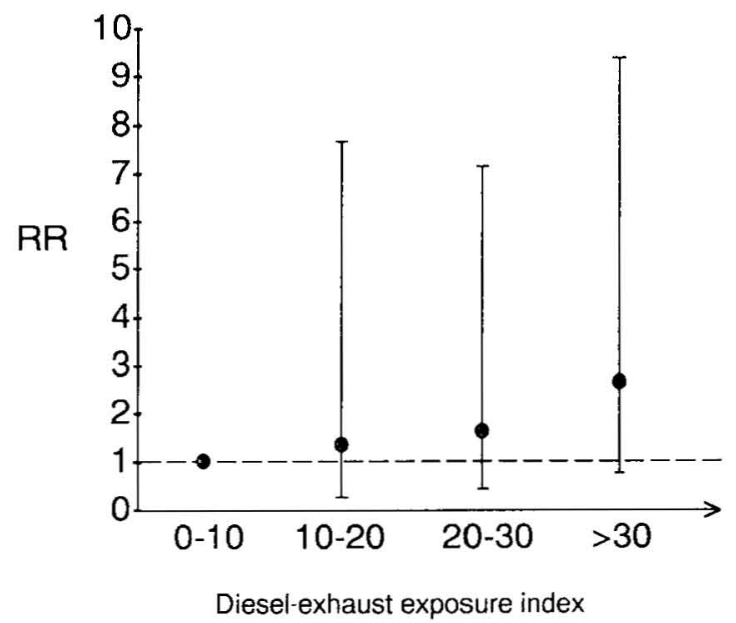

Figure 1. Estimates of the relative risk (RR) of lung cancer with logistic regression subdivided by cumulative exposure to diesel exhaust. The $95 \%$ confidence intervals are shown. pare models 1 and 2 in table 6.) The confidence intervals were wide, though, since the number of cases in each exposure group was small. Rothman has described a method for exploring the dose-response trend in a situation of this type (31). The regression coefficients (ie, the logarithms of the relative risks) of model 1 seemed to be nearly linearly correlated with the dieselexhaust index score, and a weighted regression was performed with the use of the inverse of the variance of the estimates as weights. A regression coefficient of 0.2971 with a standard error of 0.0306 was obtained. This figure can be interpreted as an increase in lung cancer risk of $35 \%$ for an increase of one level in the diesel-exhaust index score, and it corresponds closely to the relative risk of 1.37 obtained in model 2 (table 6 ). The fitted relative risks from the weighted regression and $95 \%$ confidence intervals (31) are shown in table 5 .

\section{Discussion}

The overall lung cancer mortality in the cohort was slightly increased (SMR 122). In other words, an excess of the same magnitude as in other studies of workers exposed to diesel exhaust was found. The SMR for lung cancer incidence was higher (table 2). The SMR obtained in the mortality analysis was probably the more valid one since it was standardized for geographic variations in the background rate. The lung cancer rate in Stockholm is higher than the national average.

The case-referent analysis indicated a risk excess among the highly exposed, as compared with the lowly exposed, workers, and a dose-response relationship was present. The logistic regression indicated a lung cancer risk that was 2.6 times higher for highly exposed workers than for the lowly exposed workers, although with a wide confidence interval. When data from all the dose groups were combined in the weighted linear regression, a risk excess of 2.4 was found for the highly exposed workers (95\% CI 1.3-4.5). This regression model was thus more effective but also more restrictive since a linear relationship of the logarithms of the relative risks was assumed. This condition is met in the material however; the observed relative risks corresponded closely to those predicted by the regression (table 5). The crude relative risks (table 5) were somewhat lower, probably because precision was lost when the matching was dissolved.

The dose-response trend in the SMR analysis was weak. The case-referent analysis utilized both deceased and living lung cancer cases, while the cohort analysis was limited to the deceased cases. The additional incident cases were all highly exposed to diesel exhaust.

No effect from exposure to asbestos was found. The mean asbestos exposure index was 27 , and the maximum was 86 . These index levels correspond to a cumulative asbestos exposure of approximately 2.2 and 6.0 fibers $\cdot \mathrm{ml}^{-1}$-years, respectively. Such an exposure 
would be anticipated to increase the lung cancer rate by only a few percent (32) and would not be detected in a study of this size. There were two persons with pleural mesothelioma, with cumulative asbestos exposures of 2.2 and 3.9 fibers $\cdot \mathrm{ml}^{-1}$-years, respectively. They were employed by the bus company at $2 \%$ and 30 years of age, and the tumors occurred at the ages of 63 and 64, respectively. One of them was an electrician, having worked in the electrical workshop in one of the garages. Both may have been exposed to asbestos during previous employments.

\section{Misclassification}

The exposure estimations were based on job tasks, workplace, and time periods, and the actual exposures to both diesel exhaust and asbestos have probably varied within these subgroups of the cohort. However, the exposures were classified without knowledge of the life outcome of the individuals, and thus the misclassification is independent of the outcome and may only force the relative risk towards unity (31).

The classification of the outcome (ie, the information in the registers of deaths and cancer incidence) is generally considered to be accurate (33), and since any misclassification is likely to be independent of the exposure of the individuals, it would also tend to underestimate an excess risk.

\section{Confounding}

Data on smoking habits were not possible to obtain in this retrospective study, and uncontrolled effects from tobacco smoking cannot be ruled out so far as the cohort study is concerned. In the case-referent study, however, it was not probable that the smoking habits differed substantially between the workers with high and low exposure, since both groups belonged to the same occupational category. A risk excess of 2.4 is unlikely to be explained even by extreme smoking habits (34) if it is assumed that the group with low exposure had normal smoking habits.

\section{Risk estimation}

The results of the study support the assumption that high cumulative exposure to diesel exhaust increases the risk for lung cancer. The risk excess among the highly exposed workers was greater than in other studies, possibly because of the detailed exposure assessments, which gave a good contrast between the workers with high and those with low exposure.

Total dust levels were measured during bus service and repair in one of the garages in 1981, 1982, and 1989. In 1981, personal, time-weighted 8-h samples showed a level of $1.2-1.4 \mathrm{mg} / \mathrm{m}^{3}$ (Jacobsson, unpublished data). In 1982, during $4-8 \mathrm{~h}$ of sampling, the levels were $0.5-1.0 \mathrm{mg} / \mathrm{m}^{3}$ (Bergström, unpublished data), and in 1989 they were $0.3-0.9 \mathrm{mg} / \mathrm{m}^{3}$ (Axelsson, unpublished data). Total dust is also gener- ated from sources other than the diesel engines, however, and the proportion of inorganic material in the dust was determined by etching of the samples in 1981 and 1989. The proportion varied from 50 to $62 \%$ in 1981 and from 60 to $70 \%$ in 1989 , findings indicating that most of the total dust was not generated by the diesel engines.

Substitution of these approximate data into the jobexposure matrix and into the regression model indicates a doubled lung cancer risk after 20 years of work in bus garages with a total dust level of $0.9 \mathrm{mg} / \mathrm{m}^{3}$.

The present study supports the view that diesel exhaust constitutes a cancer hazard for exposed workers. The magnitude of the risk excess can only be estimated approximately, however, due to the limited size of the study group.

\section{Acknowledgments}

We thank Ms M Söderholm for compiling the cohort data and tracing the individuals and Ms A Gustavsson for her computer work. We are also grateful to Professor A Ahlbom and Dr L Alfredsson for their valuable discussions regarding the data analysis and their comments on the manuscript. The Stockholm Transport Company kindly gave access to the source material and supported the exposure measurements.

The study was financially supported by the Folksam Insurance Group.

\section{References}

1. Lewtas $\mathbf{J}$. Evaluation of the mutagenicity and carcinogenicity of motor vehicle emissions in short-term bioassays. Environ Health Perspect 1983;47:141-52.

2. Garshick E, Schenker MB, Munoz A, et al. A casecontrol study of lung cancer and diesel exhaust exposure in railroad workers. Am Rev Respir Dis 1987;135: 1242-8.

3. Garshick E, Schenker MB, Munoz A, et al. A retrospective cohort study of lung cancer and diesel exhaust exposure in railroad workers. Am Rev Respir Dis 1988; 137:820-5.

4. Howe GR, Fraser D, Lindsay J, Presnal B, Zhang Yu $\mathrm{S}$. Cancer mortality (1965-77) in relation to diesel fume and coal exposure in a cohort of retired railway workers. J Natl Cancer Inst 1983;70:1015-9.

5. Boffetta P, Stellman SD, Garfinkel L. Diesel exhaust exposure and mortality among males in the American cancer society prospective study. Am J Ind Med 1988; $14: 403-15$.

6. Hall NEL, Wynder EL. Diesel exhaust exposure and lung cancer: a case-control study. Environ Res 1984;34:7786.

7. Waller RE. Trends in lung cancer in London in relation to exposure to diesel fumes. Environ Int 1981;5:479-3.

8. Edling C, Anjou CG, Axelson O, Kling H. Mortality among personnel exposed to diesel exhaust. Int Arch Occup Environ Health 1987;59:559-565.

9. Brightwell J, Fouillet X, Cassano-Zoppi AL, Gatz R, Duchosal F. Neoplastic and functional changes in rodents after chronic inhalation of engine exhaust emissions. Dev Toxicol Environ Sci 1986;13:471-88.

10. Heinrich U, Pott F, Mohr U, Fuhst R, König J. Lung 
tumours in rats and mice after inhalation of PAH-rich emissions. Exp Pathol 1986;29:29-34.

11. Ishinishi N, Kuwabara N, Nagase M, Suzuki T, Ishiwata $\mathrm{S}$, Kohno T. Long-term inhalation studies on effects from heavy and light diesel engines on F344 rats. Dev Toxicol Environ Sci 1986;13:329-48.

12. Iwai K, Udagawa T, Yamagishi M, Yamada H. Longterm inhalation studies of diesel exhaust on F344 SPF rats: incidence of lung cancer and lymphoma. Dev Toxicol Environ Sci 1986;13:349-60.

13. Mauderly JL, Jones RK, Griffith WC, Henderson RF, McClellan RO. Diesel exhaust is a carcinogen in rats exposed chronically by inhalation. Fund Appl Toxicol 1987;9:208-21.

14. Pederson TC, Siak J-S. The role of nitroaromatic compounds in the direct-acting mutagenicity of diesel particle extracts. J Appl Toxicol 1981;1:54-60.

15. Steenland K. Lung cancer and diesel exhaust: a review. Am J Ind Med 1986;10:177-89.

16. Hammond KS, Smith TJ, Woskie SR, Leaderer BP, Bettinger N. Markers of exposure to diesel exhaust and cigarette smoke in railroad workers. Am Ind Hyg Assoc J 1988;49:516-22.

17. Hickish DE, Knight KL. Exposure to asbestos during brake maintenance. Ann Occup Hyg 1970;13:17-21.

18. Rohl A, Langer AM, Wolff MS, Weisman I. Asbestos exposure during brake lining maintenance and repair. Environ Res 1976;12:110-28.

19. Rödelsperger K, Jahn H, Brückel B, Manke J, Paur R, Woitowitz HJ. Asbestos dust exposure during brake repair. Am J Ind Med 1986;10:63-72.

20. Kauppinen T, Korhonen K. Exposure to asbestos during brake maintenance of automotive vehicles by different methods. Am Ind Hyg Assoc J 1987;48:499-504.

21. McMichael AJ. Standardized mortality ratios and the "healthy workers effect": scratching beneath the surface. J Occup Med 1976;18:165-8.

22. National Central Bureau of Statistics. Dödsfallsregister 1961-1970 [Registry of deaths $1961-1970$ ]. Stockholm: National Central Bureau of Statistics, 1982. (SCB 1981:5.)

23. Gustavsson P. Cancer and ischemic heart disease in oc- cupational groups exposed to combustion products [Doctoral dissertation]. Stockholm: Karolinska Institute, 1989.

24. National Board of Health and Welfare, The Cancer Registry. Cancer incidence in Sweden. Stockholm: National Board of Health and Welfare, 1958-1983.

25. Breslow NE, Day NE. Statistical methods in cancer research; vol II (The design and analysis of cohort studies). Lyon: International Agency for Research on Cancer, 1987:85. (IARC scientific publications; no 82.)

26. Marsh GM, Preininger M. OCMAP: a user-oriented occupational cohort mortality analysis program. Am Stat 1980;34:245.

27. Andersson K, Anjou CG, Brodin G, Kling H, Samuelsson PJ. Datain, ratin, cohort, search, stat: dataprogram för kohortstudier: användarhandledning [Datain, ratin, cohort, search, stat: computer programs for cohort studies: user manual]. Linköping (Sweden): University of Linköping, 1982.

28. Breslow NE, Day NE. Statistical methods in cancer research; vol I (The analysis of case-control studies). Lyon: International Agency for Research on Cancer, 1980: 248-79. (IARC scientific publications; no 32.)

29. Statistics and Epidemiology Research Corporation. EGRET: user manual. Seattle, WA: Statistics and Epidemiology Research Corporation, 1988.

30. Epicenter Software. Epilog: user manual. Pasadena, CA: Epicenter Software, 1985.

31. Rothman KJ. Modern epidemiology. Boston, MA: Little, Brown and Co, 1986.

32. Doll R, Peto J. Asbestos: effects on health of exposure to asbestos. London: Health \& Safety Commission, Her Majesty's Stationery Office, 1985.

33. Mattsson B. Cancer registration in Sweden [Doctoral dissertation]. Stockholm: Karolinska Institute, 1984.

34. Axelson O. Aspects on confounding in occupational health epidemiology [Letter to the editor]. Scand J Work Environ Health 1978;4:98-102.

Received for publication: 28 June 1989 